\title{
Bioerosion ichnodiversity in barnacles from the Ross Sea, Antarctica
}

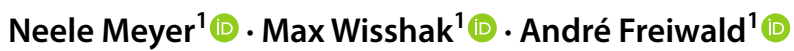

Received: 14 July 2020 / Revised: 29 January 2021 / Accepted: 2 February 2021

(C) The Author(s) 2021, corrected publication 2021

\begin{abstract}
Breakdown of skeletal and lithic hard substrates by organisms, a process referred to as bioerosion, is part of the global carbon cycle and receives increased attention, but little is known about bioerosion in polar environments. Here, we study bioerosion traces (addressed by their respective ichnotaxa) recorded in the barnacle Bathylasma corolliforme from the Ross Sea, Antarctica. Traces were visualized via scanning electron microscopy of epoxy casts prepared with the vacuum castembedding technique. In 50 samples from shallow $37 \mathrm{~m}$ to bathyal $1680 \mathrm{~m}$ water depths, 16 different bioerosion traces were found, classified into microborings presumably produced by cyanobacteria (1), chlorophytes (1), fungi (9), foraminifera (1), unknown organotrophs (5), and macroborings produced by cirripeds (1). Statistical ichnodiversity analysis resulted in a significant $(p=0.001)$ ANOSIM with moderate differences $(R=0.5)$ between microbioerosion trace assemblages at different water depths and revealed two main clusters (NMDS, SIMPROF) corresponding to the photic and aphotic stations. A comparison between this study and a corresponding study from the Svalbard archipelago, Arctic Ocean, shows that the ichnodiversity in calcareous barnacle skeletons is similar in polar waters of both hemispheres. This includes several ichnotaxa that are indicative for cool- to cold-water environments, such as Flagrichnus baiulus and Saccomorpha guttulata. Nine of the investigated ichnotaxa occur in both polar regions and seven ichnotaxa show an extensive bathymetrical range down to the deep sea at bathyal $1680 \mathrm{~m}$ water depth.
\end{abstract}

Keywords Ichnology $\cdot$ Microborings $\cdot$ Ross Sea $\cdot$ Antarctica $\cdot$ Trace fossil assemblage $\cdot$ Bathylasma corolliforme

\section{Introduction}

Bioerosion is the degradation of hard substrates by organisms (Neumann 1966) and thus a process that is part of the global carbon and carbonate cycles with a great impact on the preservation of calcareous substrates in the sedimentary record (e.g. Warme 1975; Hutchings 1986; Tribollet 2008). The various bioeroding organisms utilise a wide range of strategies to bioerode by chemical (biocorrosion) and/or mechanical (bioabrasion) means and are categorised primarily into grazers (e.g. echinoids, gastropods), macroborers (e.g. sponges, polychaetes) and microborers (e.g. fungi,

Neele Meyer

Neele.Meyer@Senckenberg.de

Max Wisshak

Max.Wisshak@Senckenberg.de

André Freiwald

Andre.Freiwald@Senckenberg.de

1 Senckenberg am Meer, Marine Research Department, Südstrand 40, 26382 Wilhelmshaven, Germany bacteria, algae) that occur in calcareous, siliceous, osteic, and xylic hard substrates. Microborings are distinguished from macroborings by their size, with either $1 \mathrm{~mm}$ trace size or $100 \mu \mathrm{m}$ tunnel diameter serving as divider (Wisshak 2012). The traces have a high fossilization potential and are addressed as trace fossil ichnotaxa, with more than 300 valid ichnospecies established so far (Wisshak et al. 2019).

Bioerosion is a process of significance on a global scale and there are comprehensive studies for trace fossil assemblages for tropical environments (e.g. Kiene and Hutchings 1994; Chazottes et al. 1995; Vogel et al. 2000; Tribollet and Golubic 2005), and warm-temperate regions, such as the Azores (Wisshak et al. 2011) and the Mediterranean Sea (Färber et al. 2015). Besides a few studies in the North Atlantic (e.g. Akpan and Farrow 1985; Schmidt and Freiwald 1993; Glaub et al. 2002; Beuck and Freiwald 2005; Wisshak 2006) and North Pacific (e.g. Young and Nelson 1988), the cold-temperate regions are poorly studied and the polar regions even less. There is a bioerosion study from the Canadian Arctic (Aitken and Risk 1988), while the Svalbard archipelago in the far North was the subject of a study 
with a focus on polychaete bioerosion (Hanken et al. 2012) and a more comprehensive microbioerosion study (Meyer et al. 2020). Bioerosion research in cooler environments is predominantly concentrated on the Northern Hemisphere, whereas the Southern Hemisphere was disregarded for a long time. Few studies were conducted in the cold-temperate region Patagonia (e.g. Ituarte et al. 2005; Malumián et al. 2006; Richiano et al. 2017; Aguirre et al. 2019) and in the polar region Antarctica. Bioeroded traces were observed on Seymour Island, Antarctica (Casadío et al. 2001, 2007), and bioerosive activities were recorded in the Ross Sea in scallops and molluscs (Alexander and DeLaca 1987; Cerrano et al. 2001; Hancock et al. 2015), and sub-fossil skeletal material (Frank et al. 2014, 2020). Together with our own data, the existing body of knowledge on polar bioerosion patterns will allow a direct comparison between both polar regions and determine tolerance limits for key bioerosion traces. Both aspects contribute to the understanding of the role of bioerosion in polar environments and therefore help broadening the knowledge of bioerosion from a local to a global scale.

In the present study, we have visualised bioerosion traces by means of the cast-embedding technique under a scanning electron microscope to: (I) compile a list of bioerosion traces preserved in barnacles from the Ross Sea, Antarctica; (II) provide data on the bathymetrical range of these ichnotaxa down to bathyal water depths; (III) statistically analyse the ichnodiversity along this bathymetrical transect (37-1680 m); and (IV) compare our findings with those of an earlier study (Meyer et al. 2020) from the Arctic Svalbard archipelago.

\section{Materials and methods}

\section{Study site}

Our samples were recovered in the Ross Sea sub-division of the Southern Ocean, between Marie Byrd Land and Victoria Land, towards the Pacific part of the Southern Ocean, south of New Zealand (Fig. 1). Although it is one of Antarctica's most intensively studied regions (Smith et al. 2007), it is an area with a very low human impact (Halpern et al. 2008).

The Ross Sea covers a broad continental shelf and water depth is shallower in the West than in the East (Fig. 1). The oceanography is governed by two clockwise rotating gyres over the continental shelves, which are synchronized with the bigger nearby Ross Sea Gyre. The gyre is driven by the westerly winds of the Antarctic Circumpolar Current (as reviewed by Smith et al. 2012).

Water temperatures range from -1.9 to $+3.2{ }^{\circ} \mathrm{C}$ and salinity ranges from 34.0 to 34.9 PSS (Smith et al. 2007, 2012). The base of the euphotic zone, where light intensity declines to $1 \%$ of the surface illumination, is at a mean depth of $34 \pm 13 \mathrm{~m}$ in spring, at ca. $26 \pm 9 \mathrm{~m}$ in summer (Smith et al. 2013), and at 14-66 m in winter (Fabiano et al. 1993), depending on seasonal variations (inter alia due to turbidity and nutrient availability, hence plankton blooms) and the
Fig. 1 Map of sample locations in the Ross Sea, Antarctica, including stations for sample collection and applied gear of recovery (more details in Table 1). Locations of additional material, not utilised for the statistical analyses, are indicated with crosses. Bathymetric data was retrieved from Arndt et al. (2013), ice shelves data for 2017 from Mouginot et al. (2017), and the sea-ice extent for July 2019 from Fetterer et al. (2017, updated daily)

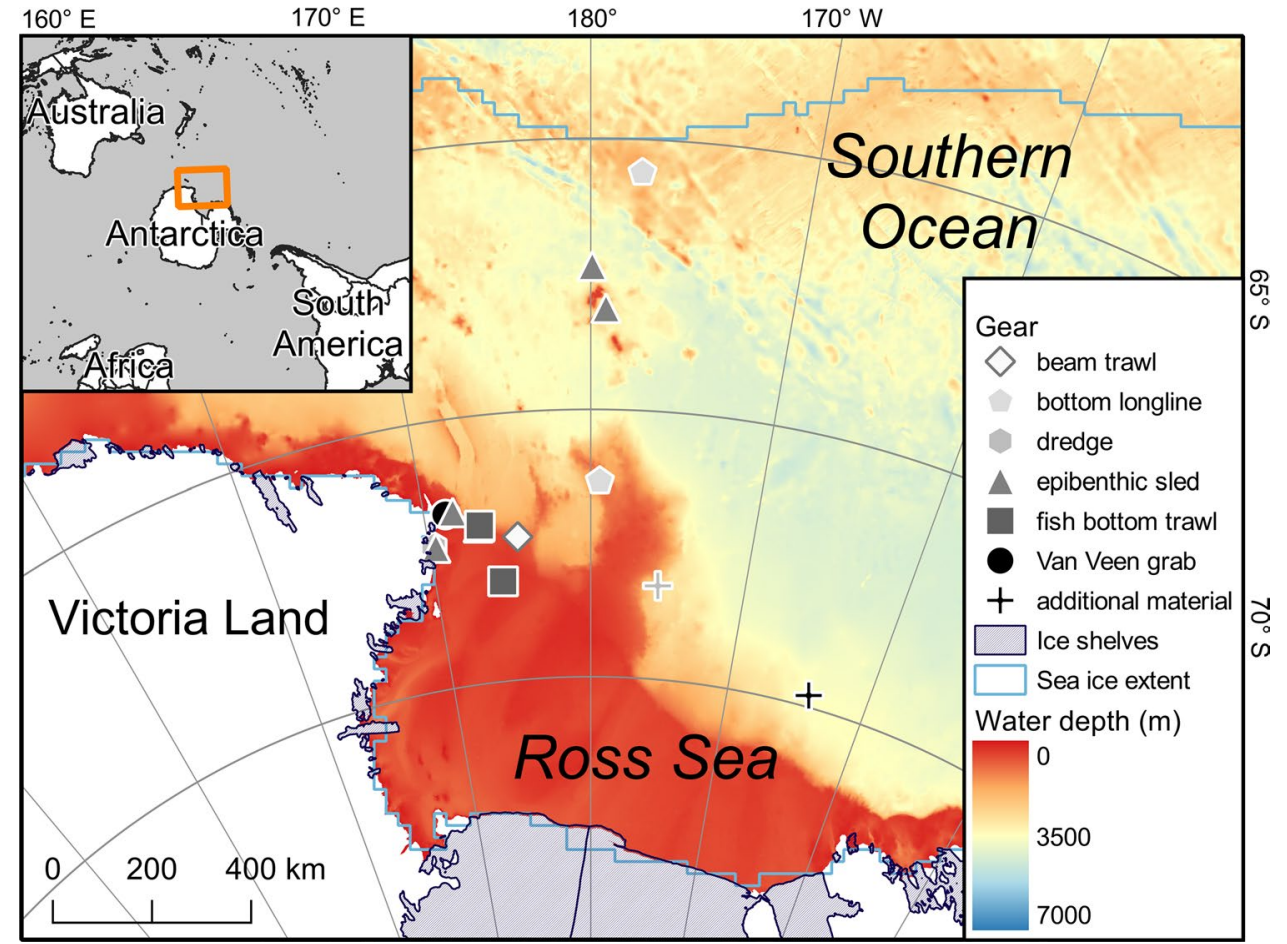


exact location within the Ross Sea (El-Sayed et al. 1983). The aphotic zone, below a transitional dysphotic zone, is below ca. $100 \mathrm{~m}$ water depth (according to Azzaro et al. 2006).

The Ross Sea is Antarctica's biologically most productive region and has the greatest phytoplankton biomass (Smith et al. 2000, 2014). Besides polar day and night, important seasonal and extreme features in the Ross Sea are sea ice (Fig. 2) and polynyas. Sea ice impedes the exchange of heat and works as an insulator between the ocean and the atmosphere, as well as affecting life in polar environments (Parkinson 2004). During winter, the sea-ice extent reaches up to $60^{\circ} \mathrm{S}$ (Smith et al. 2007; Frank et al. 2014; Fig. 1) and except for the most eastern parts, the Ross Sea is almost completely free of sea ice in January and February (Fig. 2; Parkinson 2004; excluding the Ross Ice Shelf).

\section{Sample material}

Our chosen substrates were barnacles, as several studies showed that they are well suited for bioerosion analyses (e.g. Glaub et al. 2002; Feussner et al. 2004; Meyer et al. 2020). Specimens were kindly provided by the Invertebrate Collection at the National Institute of Water and Atmospheric Research (NIWA) in Wellington, New Zealand. Barnacles were sampled from different water depths with different gear and during various cruises between 1965 and 2008 (Table 1, Fig. 1). As barnacles are sessile organisms, and since we tried to include only barnacles that were alive at the time of sampling, the recorded trace fossil assemblages are representative for the water depth of sampling, i.e. we do not have to consider time-averaging or post-mortem transport. Samples from the collection were stored in ethanol and evaporated prior to shipping. Additional material kindly provided by Marco Taviani, ISMAR-CNR, Bologna, Italy, comprised broken barnacle shells from sediments that might have experienced considerable transport (Fig. 1, Table 1) and, therefore, were excluded from the statistical analysis (Figs. 2, 3, 4).

We concentrated on the acorn barnacle species Bathylasma corolliforme (Hoek, 1883) as substrate, attached to i.e. rocks or sponges. B. corolliforme is relatively large (up to $10 \mathrm{~cm}$ ) with a long lifespan (Burgess et al. 2010; Frank et al. 2014), although no results on growth rates and longevity are available. The biology of $B$. corolliforme is poorly understood (Burgess et al. 2010), but calcification likely slows down or stops in winter due to lowered food availability. $B$. corolliforme is the predominant barnacle species in the Ross Sea (Dayton et al. 1982; Taviani et al. 1993), and an endemic circumpolar species from south of the Antarctic convergence (Newman and Ross 1971; Dayton et al. 1982). Barnacles are relatively rare in Antarctica, especially in shallow-water depths (Newman and Ross 1971). While earlier studies have stated that $B$. corolliforme does not live in depths of less than $100 \mathrm{~m}$ (Newman and Ross 1971; Dayton et al. 1982), more recent studies and our sample material (Table 1) demonstrate that they are found at least as shallow as $37 \mathrm{~m}$ (Burgess et al. 2010; Frank et al. 2014 utilised fossil fragments). Current velocities, and thus nutrient availability, are likely decisive for their vertical distribution (Dayton et al. 1982). However, also iceberg scouring is an important disturbance in shallower water depths. Up to $70 \%$ of the sea floor from 20 to $25 \mathrm{~m}$ in McMurdo Sound is affected, though the Terra Nova Bay shows nearly no disturbances (as reviewed by Smith et al. 2007). The maximum keel depth at the floating margins (hence potential icebergs) of the Ross Ice Shelf was recorded as $255 \pm 52 \mathrm{~m}$ thick (Dowdeswell and Bamber 2007).

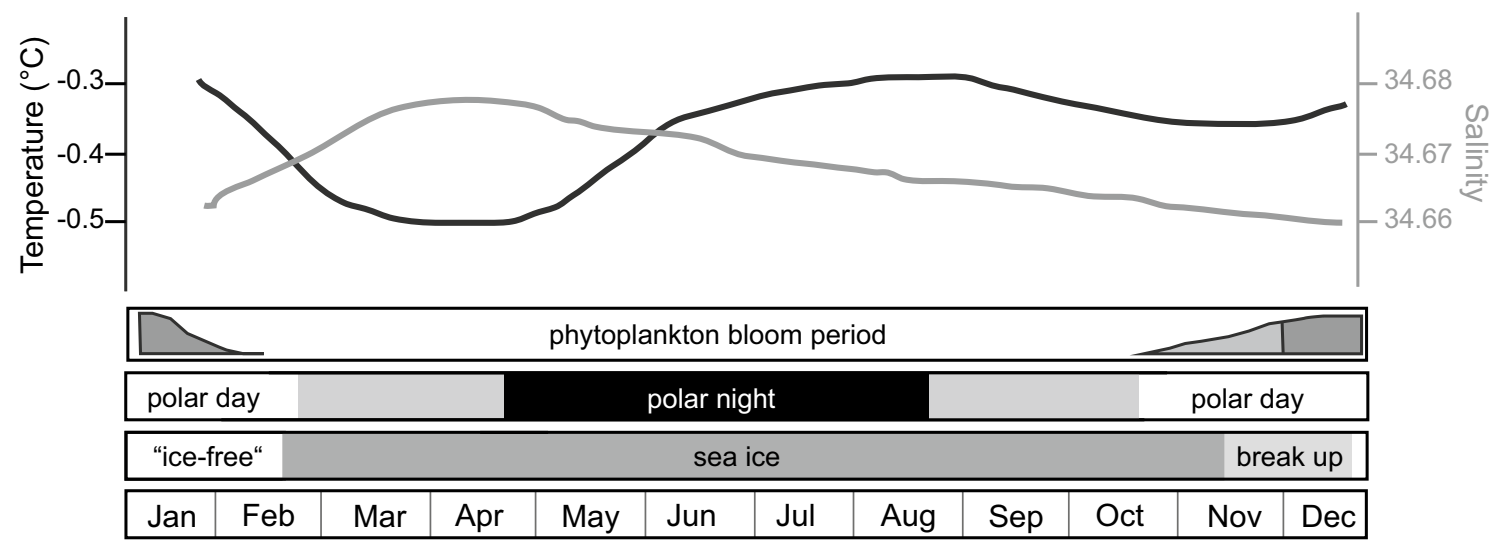

Fig. 2 Schematic overview of key environmental parameters in the Ross Sea, Antarctica. Figure 2 in Gordon et al. (2015) was traced for temperature and salinity data (from $500 \mathrm{~m}$ water depth); phytoplankton bloom is based on Asper and Smith (1999) with highest peak in mid-December to much lower levels in January to February; polar night and day data for 2004 retrieved from Thorsen (1995-2020); sea-ice data for 2004 obtained via Fetterer et al. (2017, updated daily) - in January, there was still some sea ice left, but the Ross Sea was mostly ice free 
Table 1 List of analysed Bathylasma corolliforme, including water depth during recovery, station ID, date of collection, coordinates (at start of deployment), and gear

\begin{tabular}{|c|c|c|c|c|c|c|}
\hline Depth (m) & Station ID & Collection date & Latitude & Longitude & Gear & $\begin{array}{l}\text { No. of } \\
\text { samples }\end{array}$ \\
\hline 37 & E182 & $19 / 01 / 1965$ & -72.305 & 170.271 & Dredge, cone mesh with bag & 4 \\
\hline 154 & TAN0402/52 & $12 / 02 / 2004$ & -72.337 & 170.394 & Epibenthic sled & 4 \\
\hline 277 & TAN0402/30 & $09 / 02 / 2004$ & -71.746 & 171.291 & Van Veen grab & 4 \\
\hline 321 & TAN0802/17 & $09 / 02 / 2008$ & -73.125 & 174.321 & Fish bottom trawl & 4 \\
\hline 466 & TAN0402/15 & $05 / 02 / 2004$ & -71.728 & 171.735 & Epibenthic sled & 4 \\
\hline 538 & TAN0402/74 & $14 / 02 / 2004$ & -72.073 & 173.136 & Epibenthic sled & 4 \\
\hline 620 & TAN0402/72 & $13 / 02 / 2004$ & -72.061 & 173.245 & Epibenthic sled & 4 \\
\hline 770 & TAN0402/85 & $14 / 02 / 2004$ & -72.037 & 173.249 & Fish bottom trawl & 4 \\
\hline 879 & TAN0802/206 & $03 / 03 / 2008$ & -68.121 & -179.248 & Epibenthic sled & 3 \\
\hline 980 & TAN0802/129 & $21 / 02 / 2008$ & -72.317 & 175.489 & Beam trawl & 3 \\
\hline 1130 & TAN0802/256 & $08 / 03 / 2008$ & -67.340 & -179.932 & Epibenthic sled & 4 \\
\hline 1310 & TRIP2731/49 & $13 / 01 / 2009$ & -71.332 & -179.475 & Bottom longline & 4 \\
\hline 1680 & TRIP2730/9 & $09 / 12 / 2008$ & -65.603 & -177.710 & Bottom longline & 4 \\
\hline 214 & CARBONAT_Carb10 & $16 / 01 / 2002$ & -74.783 & -164.170 & Van Veen grab & 4 \\
\hline 389 & CARBONAT_Carb34 & $16 / 01 / 2002$ & -73.243 & -175.639 & Dredge & 4 \\
\hline
\end{tabular}

The latter two entries list data for the additional sample material, not utilised for the statistical analyses

\section{Cast-embedding technique}

The cast-embedding technique is a common method to visualise bioerosion traces (Golubic et al. 1970; Wisshak 2006, 2012). The barnacles were soaked for $24 \mathrm{~h}$ in sodium hypochlorite (customary cleaning agent) to remove organic material and afterwards rinsed several times with deionised water. The cleaned skeletal elements were dried at $30{ }^{\circ} \mathrm{C}$ in a drying cabinet. The bioeroded tunnels inside the barnacle armour were subsequently filled with R\&G "water clear" epoxy resin in a CitoVac (Struers) vacuum chamber. The samples cured for 4-5 days before dissection with a rock saw. During treatment with ca. $5 \%$ hydrochloric acid, the calcareous barnacle shells dissolved, and the pieces fell apart. Fifty samples were sputter-coated with gold (Cressington sputter coater 108) and analysed under a scanning electron microscope (SEM, Tescan VEGA3 xmu) using the secondary electron detector at $20 \mathrm{kV}$ acceleration voltage.

\section{Identification, quantification and statistical analyses}

Bioerosion traces were identified to the ichnospecies level and morphological forms yet untreated in ichnotaxonomy were assigned to informal names. We conducted a semiquantitative analysis, because an actual quantification is unfeasible for bioerosion traces (due to a wide range of sizes, colonies vs. single borings, etc.), and gathered ordinal data in that each ichnotaxon/form recorded in each sample were categorised into one of five abundance classes (absent $=0$; very rare, only one or very few specimens $=1$; rare, few specimens $=2$; common, many specimens but not dominant $=3$; very common or dominant $=4$ ), following the approach of assessing ichnodiversity outlined by Wisshak et al. (2011) and Meyer et al. (2020).

To analyse our data as a multivariate data set, we used each sample individually. We utilised $\mathrm{R}$ version 3.6.2 ( $\mathrm{R}$ Core Team 2019) and the package "MVN" (Korkmaz et al. 2014) to perform both Mardia and Royston multivariate normality tests. Data were not transformed, because they are on an ordinal scale, and transformation is not required for the following non-parametric tests. The package "vegan" (Oksanen et al. 2018) was used for ANOSIM (ANalysis Of SIMilarities; with 999 permutations) and for the NMDS (Non-metric Multi-Dimensional Scaling) plots, whilst the package "clustsig" (Whitaker and Christman 2014) was used for the cluster analyses with SIMPROF (SIMilarity PROFile; with the cluster method 'average'). Prior to the tests, we computed a Bray-Curtis dissimilarity matrix with "vegan", which is common practice for an ANOSIM (Hammer and Harper 2008; Greenacre and Primicerio 2013). The biodiversity indices (i.e. ichnodiversity indices) Margalef's richness index $d$, Simpson index of dominance $\lambda$ and diversity $1-\lambda$, Shannon index $H^{\prime}\left(\log _{e}\right)$, and Pielou's evenness $J$ ' were also calculated with $\mathrm{R}$. We computed the indices based on ranked semi-quantitative abundance data by transforming the abundance classes as follows (based on Wisshak et al. 2011): ' 4 ' to 1000 ; ' 3 ' to 100 ; ' 2 ' to 10 , and ' 1 'as 1 per sample, to obtain relative abundances. Subsequently, we calculated means per water depth and a grand mean. 

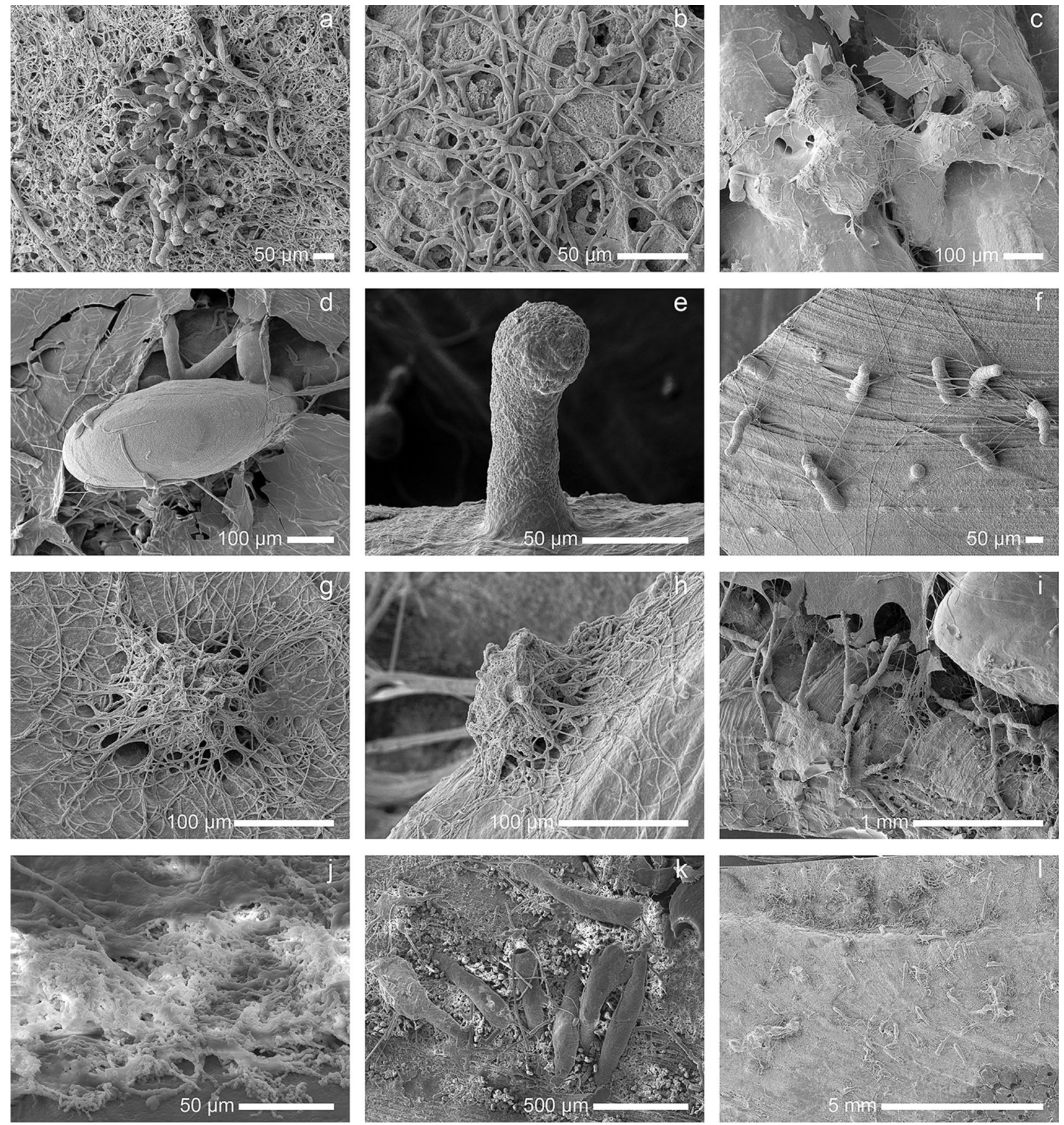

Fig. 3 Microborings produced (inferred or assumed) by cyanobacteria, chlorophytes, barnacles, bacteria, or unknown organotrophs a Fascichnus frutex from $37 \mathrm{~m}$ water depth b Ichnoreticulina elegans from $37 \mathrm{~m}$ water depth c Pyrodendrina villosa from $466 \mathrm{~m}$ water depth d Rogerella isp. from $466 \mathrm{~m}$ water depth e Finger-form from
879 m water depth $\mathbf{f}$ Finger-form from $277 \mathrm{~m}$ water depth $\mathbf{g}$ Nidusform from $620 \mathrm{~m}$ water depth $\mathbf{h}$ Lateral view of Nidus-form from $620 \mathrm{~m}$ water depth i Proturbero-form from $466 \mathrm{~m}$ water depth j Scolecia serrata from additional sample material $\mathbf{k}$ close-up of Clavateform from $214 \mathrm{~m}$ water depth I Clavate-form from $214 \mathrm{~m}$ water depth 



Fig. 4 Microborings of inferred or assumed fungal origin a Flagrichnus baiulus from $154 \mathrm{~m}$ water depth b Flagrichnus baiulus from $1130 \mathrm{~m}$ water depth with atypical elongated chambers c Flagrichnus baiulus from $1130 \mathrm{~m}$ water depth d Flagrichnus cf. baiulus from $1130 \mathrm{~m}$ water depth e Flagrichnus-form I from $466 \mathrm{~m}$ water depth f Saccomorpha clava from $1310 \mathrm{~m}$ water depth $\mathbf{g}$ Saccomorpha guttu- lata from $980 \mathrm{~m}$ water depth $\mathbf{h}$ Orthogonum-form I from $620 \mathrm{~m}$ water depth i Orthogonum lineare from $879 \mathrm{~m}$ water depth j Orthogonum giganteum from $277 \mathrm{~m}$ water depth $\mathbf{k}$ juvenile stage of four Polyactina araneola from $879 \mathrm{~m}$ water depth $\mathbf{l}$ adult stage of Polyactina araneola from $879 \mathrm{~m}$ water depth 
Table 2 List of ichnotaxa recorded from the Ross Sea, together with the inferred or assumed (in brackets) trace makers, based on the original interpretation of the ichnotaxon authority, and some descriptive

\begin{tabular}{|c|c|c|c|}
\hline Trace maker & Ichnotaxon/form & Remarks & Figure \\
\hline Cyanobacteria Hyella gigas & Fascichnus frutex (Radtke, 1991) & - & Figure $3 a$ \\
\hline Chlorophyte Ostreobium quekettii & Ichnoreticulina elegans (Radtke, 1991) & The surface was rarely a bit fuzzy & Figure $3 b$ \\
\hline (Fungi) & Flagrichnus baiulus Wisshak and Porter, 2006 & $\begin{array}{l}\text { Highly diverse, occasionally "dendritic" form, } \\
\text { rarely with undescribed elongated chambers }\end{array}$ & Figure $4 a-c$ \\
\hline (Fungi) & Flagrichnus cf. baiulus & See text & Figure $4 d$ \\
\hline (Fungi) & Flagrichnus-form I & See text & Figure $4 \mathrm{e}$ \\
\hline Fungi Dodgella prisca & Saccomorpha clava Radtke, 1991 & $\begin{array}{l}\text { Sometimes a pronounced collar around the } \\
\text { base }\end{array}$ & Figure $4 \mathrm{f}$ \\
\hline (Fungi) & Saccomorpha guttulata Wisshak et al., 2018 & $\begin{array}{l}\text { Occasionally similarities to young stage of } \\
\text { Polyactina araneola }\end{array}$ & Figure $4 \mathrm{~g}$ \\
\hline (Fungi) & $\begin{array}{l}\text { Orthogonum-form I sensu Wisshak et al., } \\
2005\end{array}$ & See text & Figure $4 \mathrm{~h}$ \\
\hline (Fungi) & Orthogonum lineare Glaub, 1994 & - & Figure $4 \mathrm{i}$ \\
\hline (Fungi) & Orthogonum giganteum Glaub, 1994 & - & Figure $4 \mathrm{j}$ \\
\hline Fungi Conchyliastrum merritti & Polyactina araneola Radtke, 1991 & Highly diverse, occurred at different stages & Figure $4 k-1$ \\
\hline (Foraminifera) & Pyrodendrina villosa Wisshak, 2017 & - & Figure $3 c$ \\
\hline Unknown & Finger-form & See text & Figure $3 e-f$ \\
\hline Unknown & Nidus-form & See text & Figure $3 \mathrm{~g}-\mathrm{h}$ \\
\hline Unknown & Proturbero-form & See text & Figure $3 \mathrm{i}$ \\
\hline Acrothoracid barnacles & Rogerella isp. de Saint-Seine, 1951 & Macroboring & Figure $3 d$ \\
\hline (Bacteria) & Scolecia serrata Radtke, 1991 & Observed in additional sample material & Figure $3 \mathrm{j}$ \\
\hline Unknown & Clavate-form & $\begin{array}{l}\text { Observed in additional sample material, see } \\
\text { text }\end{array}$ & Figure $3 k-1$ \\
\hline
\end{tabular}

The last two ichnotaxa in the list were noted in additional sample material and are listed for completeness, but not included in the statistical analysis

As indices are usually based on counts of specimens (Hammer and Harper 2008), this approach allows an evaluation of relative abundance.

\section{Results}

\section{List of bioerosion traces}

We recorded sixteen different bioerosion traces (respectively ichnotaxa) in our samples; one of them was presumably produced by cyanobacteria, one by chlorophytes, nine by fungi, one by foraminifera, one by barnacles, and three unknown forms were produced by unidentified organotrophs and listed with informal names (Table 2; Figs. 3, 4).

Detailed results of the semi-quantitative analysis of the bioerosion traces are provided in Table 3 . The ichnocoenoses and ichnodiversity varied between water depths, with the highest ichnospecies richness at $466 \mathrm{~m}$ (12 different traces), the second largest ichnospecies richness at $277 \mathrm{~m}$ (seven traces), and the lowest diversity at $980 \mathrm{~m}$ (two traces). Whilst ichnotaxa presumably produced by photosynthesising bioeroders at shallow-water depths (Fascichnus frutex, remarks with respect to differences in morphology compared to the original diagnoses 
Table 3 Results of semi-quantitative analysis of bioerosion traces in the Ross Sea

\begin{tabular}{|c|c|c|c|c|c|c|c|c|c|c|c|c|c|}
\hline \multirow[t]{2}{*}{ Ichnotaxon/form } & \multicolumn{13}{|c|}{ Water depth $(\mathrm{m})$} \\
\hline & 37 & 154 & 277 & 321 & 466 & 538 & 620 & 770 & 879 & 980 & 1130 & 1310 & 1680 \\
\hline Fascichnus frutex (Radtke, 1991) & -- & & & & & & & & & & & & \\
\hline Ichnoreticulina elegans (Radtke, 1991) & ++ & & & & & & & & & & & & \\
\hline Flagrichnus baiulus Wisshak and Porter, 2006 & & + & - & - & -- & - & - & -- & -- & -- & - & + & - \\
\hline Flagrichnus cf. baiulus & & -- & -- & -- & -- & - & -- & & & & -- & -- & -- \\
\hline Flagrichnus-form I & & & -- & & -- & -- & & -- & & & & & \\
\hline Saccomorpha clava Radtke, 1991 & & & & & & -- & & & -- & & -- & ++ & -- \\
\hline $\begin{array}{l}\text { Saccomorpha guttulata } \\
\text { Wisshak et al., } 2018\end{array}$ & & - & -- & -- & ++ & - & -- & -- & - & -- & - & ++ & \\
\hline Orthogonum-form I sensu Wisshak et al., 2005 & & & & & -- & & -- & -- & & & & & \\
\hline Orthogonum lineare Glaub, 1994 & & & & & -- & & & & -- & & -- & -- & \\
\hline Orthogonum giganteum Glaub, 1994 & -- & & -- & & -- & & & & & & & & \\
\hline Polyactina araneola Radtke, 1991 & & & & & - & & & -- & - & & - & - & \\
\hline Pyrodendrina villosa Wisshak, 2017 & -- & -- & -- & & - & & & & & & & & \\
\hline Finger-form & -- & -- & -- & & -- & & & & -- & & & & -- \\
\hline Nidus-form & -- & & & & & & -- & & & & & & \\
\hline Proturbero-form & & & & & -- & & & & & & & & \\
\hline Rogerella isp. de Saint-Seine, 1951 & & & & & - & & & & & & & & \\
\hline Number of ichnotaxa/forms & 6 & 5 & 7 & 3 & 12 & 5 & 5 & 5 & 6 & 2 & 6 & 6 & 4 \\
\hline
\end{tabular}

Abundances are categorised as ' $++{ }^{\prime}=$ very common, ' + ' $=$ common, ' - ' $=$ rare, and ' $--^{\prime}$ '= very rare, excluding data from the additional sample material

out than described in the original diagnosis (Fig. 4d, Meyer et al. 2020).

\section{Flagrichnus-form I}

Flagrichnus-form I is another microboring with affinity to the ichnogenus Flagrichnus. It has similar characteristics, but larger $(>15 \mu \mathrm{m})$ sac-shaped cavities (Wisshak and Porter 2006), which merge to a greater extent. The trace is up to $150 \mu \mathrm{m}$ in diameter (Fig. 4e).

\section{Orthogonum-form I sensu Wisshak et al., 2005}

Orthogonum-form I exhibits a sinuous morphology and runs closely parallel to the substrate, with a tunnel diameter of 3-5 $\mu \mathrm{m}$. This microboring was also recognised by Wisshak et al. (2005) and Meyer et al. (2020) (Fig. 4h).

\section{Finger-form}

This single-tunnel-trace has the morphology of fingers and occasionally occurs in a cluster of up to 10 . It penetrates straight and deep into the substrate (up to $200 \mu \mathrm{m}$ ) and is up to $50 \mu \mathrm{m}$ wide at the base, slightly thinning towards the convex ends (Fig. 3f).

\section{Nidus-form}

Nidus-form has a certain resemblance to a nest (lat. "nidus"). The trace is a pit-shaped boring $>175 \mu \mathrm{m}$ in diameter, almost completely covered by thin filaments (tunnel width: $1-3 \mu \mathrm{m}$ ), which form a bundle on top of the pit, before they run closely parallel to the substrate for several mm (Fig. 3g-h).

\section{Proturbero-form}

The Proturbero-form (lat. "stand out") is comparatively large. The tunnel-system with widths of up to $75 \mu \mathrm{m}$ is irregular with bulbous swellings in the course. Bifurcations are often rectangular, but sometimes the tunnels split randomly into two to four. The beginning of the tunnels is usually wider and gets thinner towards the bifurcations (Fig. 3i).

\section{Additional sample material}

We also investigated a few additional samples from the Ross Sea (Fig. 1, Table 1). However, therein observed ichnotaxa were excluded from the semi-quantitative and subsequent statistical analysis, because the samples were isolated barnacle skeletal elements from sediment samples that do not necessarily record the actual water depth of the living animal. We recorded two further microborings, which were 
not noticed in the other material, and added them to the ichnotaxa list from the Ross Sea. We found Scolecia serrata Radtke, 1991 by (inferred) bacteria, and an unknown bioerosion trace:

\section{Clavate-form}

This bioerosion trace has planar and slightly clavate tunnels with convex ends, which are wider than $100 \mu \mathrm{m}(>160 \mu \mathrm{m})$, with a length of up to $830 \mu \mathrm{m}$. They run either parallel or are collapsed to the substrate surface. In the single sample, they occur in irregular clusters, occasionally parallel or crossing each other. In two cases, several tunnels emerged from a deformed central point of entry (Fig. 3k-1).

\section{Statistical ichnodiversity analyses}

As the Mardia and Royston normality tests both resulted in $p<0.001$, normality was rejected, and we performed the non-parametric, multivariate ANOSIM to statistically test differences between groups (= water depths). ANOSIM resulted in $R=0.5022$ with a significance $=0.001$ (significant). The possible and actual permutations were 35 .

The NMDS result (Fig. 5a) together with the cluster analysis with SIMPROF (Fig. 5b) show a clear distinction in two clusters, a small one for the few samples from the photic zone and a more widely scattered one for all aphotic stations (stress $=0.11$ ). In the SIMPROF analysis (Fig. 5b), the two respective main branches diverge at height 3.48. There is sub-clustering below height 2.5 within the branch that contains all the aphotic stations that appears independent of the water depth without any other obvious difference.
Besides samples from $466 \mathrm{~m}$ depth with high species richness, the (ichno)diversity indices yielded similar values along the bathymetric transect, though varying within the same water depth (not shown herein). The Shannon index $H^{\prime}\left(\log _{e}\right)$ and Pielou's evenness $J$ ' vary a little more than the Simpson indices (details in Table 4). However, there is an overall trend of a decreasing Simpson index of dominance $\lambda$ and general increase of the Shannon index $H^{\prime}\left(\log _{e}\right)$ from the photic to greater water depths. Thus, the shallowest station has a high dominance of one single dominant taxon $(\lambda$ close to 1 ; Ichnoreticulina elegans $)$ and a low diversity $(1-\lambda$ close to $0 ; H^{\prime}\left(\log _{e}\right)$ close to 0$)$.

\section{Discussion}

\section{Ichnotaxa from the Ross Sea}

The wide continental shelf of the Ross Sea is in an extreme environment regarding the seasonal formation of sea ice and the variable light regime including polar night and day. It is one of the most comprehensively studied regions of the Southern Ocean and has a comparatively high species richness (Clarke et al. 2007). However, the process of bioerosion and the ichnodiversity of bioerosion traces have received very little attention, a fact that applies for entire Antarctica.

Sixteen different microbioerosion traces were observed in barnacles from the Ross Sea. One of the traces was bioeroded by chlorophytes, one by cyanobacteria, nine by fungi, one by foraminifera, one by barnacles, and three traces are yet of unknown affinity. Two further microborings were noticed in additional sample material - one by bacteria



Fig. 5 NMDS plots for the a ichnodiversity at Ross Sea and respective results of the cluster analyses with b SIMPROF, with two principal clusters represented by all stations from the photic zone versus those from the aphotic zone. Several clusters of points were drawn

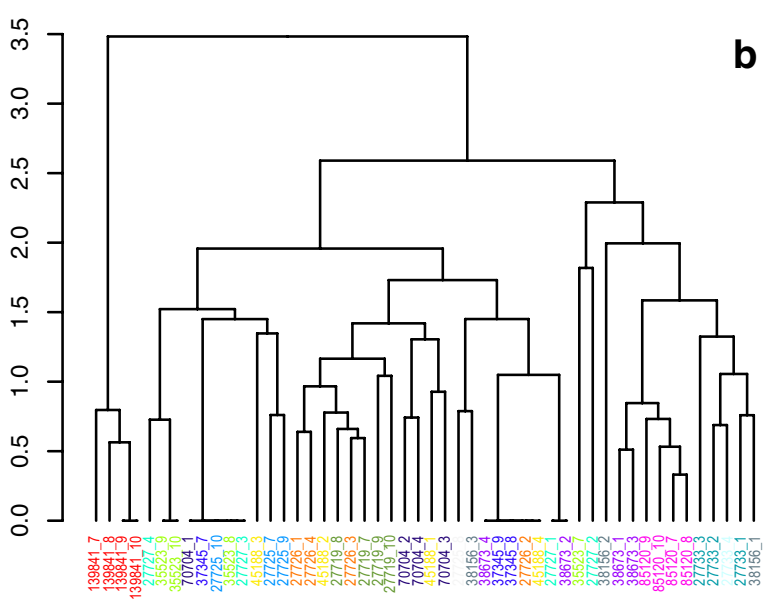

apart for the purpose of presentation, as some of the dots were on top of each other. The long numbers indicate the catalogue number of the NIWA, and the short numbers refer to the sample number 
Table 4 Calculated mean of ichnodiversity indices of ichnotaxa in the Ross Sea per water depth, with a grand mean and a mean without the shallowwater samples

\begin{tabular}{lllllll}
\hline Water depth (m) & $\begin{array}{l}\text { Ichnospe- } \\
\text { cies rich- } \\
\text { ness } S\end{array}$ & $\begin{array}{l}\text { Margalef's } \\
\text { richness } \\
\text { index } d\end{array}$ & $\begin{array}{l}\text { Simpson index } \\
\text { of dominance } \lambda\end{array}$ & $\begin{array}{l}\text { Simpson index } \\
\text { of diversity } 1-\lambda\end{array}$ & $\begin{array}{l}\text { Shan- } \\
\text { non index } \\
H^{\prime}\left(\log _{e}\right)\end{array}$ & $\begin{array}{l}\text { Pielou's } \\
\text { evenness } \\
J^{\prime}\end{array}$ \\
\hline 37 & 3.00 & 0.29 & 0.99 & 0.01 & 0.04 & 0.03 \\
154 & 3.50 & 0.84 & 0.76 & 0.24 & 0.41 & 0.42 \\
277 & 3.25 & 1.35 & 0.47 & 0.54 & 0.90 & 0.82 \\
321 & 1.25 & 0.48 & 0.88 & 0.13 & 0.17 & 1.00 \\
466 & 6.25 & 0.94 & 0.72 & 0.28 & 0.55 & 0.34 \\
538 & 3.50 & 1.20 & 0.50 & 0.50 & 0.89 & 0.73 \\
620 & 2.25 & 0.76 & 0.72 & 0.28 & 0.49 & 0.65 \\
770 & 2.50 & 1.81 & 0.52 & 0.48 & 0.80 & 1.00 \\
879 & 3.00 & 0.54 & 0.67 & 0.33 & 0.55 & 0.50 \\
980 & 1.67 & 1.44 & 0.67 & 0.33 & 0.46 & 1.00 \\
1130 & 3.75 & 0.90 & 0.57 & 0.43 & 0.76 & 0.66 \\
1310 & 4.75 & 0.55 & 0.60 & 0.41 & 0.72 & 0.47 \\
1680 & 2.25 & 1.31 & 0.57 & 0.43 & 0.66 & 0.93 \\
Grand mean & 3.15 & 0.96 & 0.66 & 0.34 & 0.60 & 0.66 \\
w/o 37 m & 3.16 & 1.01 & 0.64 & 0.36 & 0.61 & 0.71 \\
\hline
\end{tabular}

and one of unknown origin (Table 2, Figs. 3, 4). Finger-, Nidus-, and Proturbero-form are unspecified yet and have no similarity to the morphology of any known ichnotaxa. Fascichnus frutex and Ichnoreticulina elegans are ichnotaxa bioeroded by phototrophic cyanobacteria and chlorophyte algae, respectively, and account for the smallest share of the ichnospecies richness (Table 2), whereas fungal microborings constitute the largest share.

We do not entirely agree with the few identifications of (micro)bioerosion traces in previous studies from the Ross Sea, which listed Trypanites, Scolecia serrata, Flagrichnus baiulus, and microborings by sponges (Frank et al. 2014, 2020). The investigated two-dimensional thin sections bear limitations in addressing three-dimensional bioerosion traces. In particular, we doubt the identification of sponge borings (Fig. 9c in Frank et al. 2014; Fig. 7a and b in Frank et al. 2020) and suggest that those "forms of branching galleries" (Frank et al. 2020) are perhaps internal canals of stylasterid coral such as those visualised in Wisshak et al. (2009; Fig. 5) with the cast-embedding technique. In our opinion, Fig. 9b in Frank et al. (2014) and Fig. 7a in Frank et al. (2020) do not allow a clear assignment to Trypanites. Furthermore, we would tentatively identify the trace assigned to F. baiulus in Fig. 7c in Frank et al. (2020) as Saccomorpha guttulata (Wisshak et al. 2018). The identification of Scolecia serrata in Fig. 7d in Frank et al. (2020) appears reasonable, but it is an ichnotaxon and not its producer. The bioerosion traces illustrated in Fig. 1 by Cerrano et al. (2001) are difficult to address but likely show Ichnoreticulina elegans, a very common trace produced by the chlorophyte alga Ostreobium quekettii Bornet and Flahault, 1889. Hence, there are no reports of ichnotaxa from Antarctica in the literature that would complement the microbioerosion trace diversity we have recorded from the Ross Sea.

\section{Bathymetric distribution of ichnotaxa}

The bathymetric distribution of ichnotaxa in our study is similar to the usual bathymetric zonation pattern of microendolithic borings, which comprises typically a dominance of cyanobacterial borings from the supratidal down to the deep euphotic zone, complemented by chloro- and rhodophyte borings in the euphotic down to the dysphotic zone, and the exclusive occurrence of traces formed by fungi and other organotrophs in the aphotic zone (e.g. Golubic et al. 1975; Schmidt 1992; Glaub 1994; Vogel et al. 2000; Glaub et al. 2002; Wisshak 2012).

Among the traces we have recorded, Fascichnus frutex and Ichnoreticulina elegans are the only ichnotaxa produced by photosynthesising organisms and were exclusively recorded in the upper water column (euphotic zone). Their trace makers, the cyanobacterium Hyella gigas Lukas and Golubic, 1983 and the chlorophyte alga Ostreobium quekettii, respectively, appear to cope well with the polar night and its almost complete absence of photosynthetic active radiation (Fig. 2). The photic zonation at such a high latitude is strongly condensed, so that only our $37 \mathrm{~m}$ station was within the photic zone. Barnacles are rare in that zone of the Ross Sea (Newman and Ross 1971), because of sea-ice abrasion (Smith et al. 2007). More samples from shallower depths would probably have led to the recognition of further microborings of phototrophic euendoliths, thus our present inventory has a shortcoming for the shallow euphotic zone. 
The vast majority of microborings in aphotic waters with known trace makers are produced by organotrophic organisms (e.g. Golubic et al. 1975; Schmidt 1992; Glaub et al. 2002; Beuck and Freiwald 2005), such as fungi. They thrive in all environments and are very stable towards varying environmental conditions, which is confirmed by the often cosmopolitan distribution of their traces (Table 3; Golubic et al. 2005; Wisshak 2012). Fungi are independent of light, but dependent on substrates with organic content to feed on (as reviewed by Golubic et al. 2005). Trace makers are not yet known for all the recorded ichnotaxa assigned to a fungal producer (Table 2), although an organotrophic producer is inferred from the trace morphology and occurrence down to bathyal water depths. For the Finger-, Nidus-, and Proturbero-form, we can likewise assume an organotrophic trace maker due to their distribution in the aphotic zone.

We provide first observations of several ichnotaxa (e.g. Flagrichnus baiulus, Saccomorpha clava) for the deep sea down to water depths of $1680 \mathrm{~m}$. Saccomorpha clava and Saccomorpha guttulata are very abundant at $1310 \mathrm{~m}$, coexisting with Polyactina araneola, Orthogonum lineare, and Flagrichnus baiulus and Flagrichnus cf. baiulus (Table 3), all bioeroded by organotrophic trace makers (likely fungi). Flagrichnus baiulus is so far the only ichnotaxon found at deeper water depths (3266 m; Hook and Golubic 1993). Previous microbioerosion studies that have identified microbioerosion traces were conducted in shallower water depths in, for instance, the Bahamas (210 to $1450 \mathrm{~m}$; Zeff and Perkins 1979), Puerto Rico (down to $500 \mathrm{~m}$; Budd and Perkins 1980), the western North Atlantic Ocean (down to 871 m; Hook et al. 1984), the Porcupine Seabight (northeastern Atlantic Ocean, down to $650 \mathrm{~m}$; Beuck and Freiwald 2005), and the Azores (down to $500 \mathrm{~m}$; Wisshak et al. 2011). Although these studies were not conducted in high latitudes or in the Southern Hemisphere, the same microborings (such as Saccomorpha clava in Zeff and Perkins 1979 or Flagrichnus baiulus in Hook and Golubic 1993) were detected, because the deep sea has generally similar environmental parameters at all latitudes as far as cold temperatures and an aphotic light regime are concerned.

It is a widespread conception that biodiversity decreases with water depth. However, for benthic invertebrates in the Southern Ocean, it has been shown that bivalves, gastropods, and polychaetes have a roughly constant species richness between 1000 and $6000 \mathrm{~m}$ water depth (Brandt et al. 2009). Our results suggest that this applies also for the ichnodiversity of microbioerosion traces between 154 and $1680 \mathrm{~m}$ water depth in the Ross Sea (Table 3).

\section{Statistical evaluation of the bioerosion ichnodiversity}

As an aim of this study is a comparison between the high latitudes in the North and the South, we applied the same statistical outline as Meyer et al. (2020), and tested whether bathymetry (i.e. a reflection of the availability of light) has a significant impact on the ichnodiversity.

The number of ichnotaxa, their abundance, and the ichnodiversity varies with water depth (Table 3 ). Bioerosion traces by phototrophic organisms were detected, as expected, exclusively in the shallow-water samples, whilst borings by organotrophic organisms dominate the deeper water samples. The significant ANOSIM demonstrates moderate differences $(R$-value $=0.5022)$ between sampling depths, as our bathymetric transect covers mainly the aphotic zone, with roughly the same ichnotaxa occurring at all depth stations (Table 3). The observation is confirmed by the NMDS and cluster analysis, that both show a separation into two main clusters, represented by our photic and aphotic stations (Fig. 5).

The statistical analysis might be affected to some degree by a sampling bias: specimens from $466 \mathrm{~m}$, for instance, were up to $6 \mathrm{~cm}$ long and showed the highest ichnodiversity, whereas specimens from $980 \mathrm{~m}$ were only $0.8 \mathrm{~cm}$ long and had the lowest number of traces, implying that the age of the host organism might be a controlling factor on the observed ichnotaxa assemblages, as this has an influence on the time allowed for larvae of microendoliths to infest the substrate. Also, there are opportunistic and rather slow settlers, and different microendoliths may bioerode at different rates (e.g. reviewed by Wisshak 2006), leading to a succession of bioerosion stages (e.g. Beuck and Freiwald 2005). However, we observed no evident correlation between sample size and number of traces. An additional potential sampling bias might be that cover plates and armour plates were analysed but not both at every depth station. In the course of test series for our corresponding study on samples from Svalbard (Meyer et al. 2020) we had noted that bioerosion intensity and ichnodiversity was lower in the cover plates, possibly because they are in motion and in the reach of the animals feeding organs.

The mean ichnodiversity indices varied little along the bathymetric (mainly aphotic) transect, although a general trend of a decreasing dominance and increasing evenness is noticeable due to the switch from the photic to the aphotic zone. The shallowest station is marked with a high dominance of one ichnotaxon by a phototrophic bioeroder (Simpson $\lambda$ very close to 1 ), confirmed with a low Shannon diversity $H^{\prime}$ and evenness $J^{\prime}$. According to the grand mean, the assemblages have a moderate dominance of ichnotaxa, and they are rather equally common than very different. The 
results are similar with or without the shallow-water samples (Table 4), reducing the impact of the shallow-water samples.

\section{Ichnotaxa in the polar North and South}

To put the ichnodiversity of the Antarctic Ross Sea in a wider context, we here compare our findings to our previous study of microbioerosion traces in Arctic barnacles (Balanus balanus and Balanus crenatus) from the Svalbard archipelago (Meyer et al. 2020), as both studies follow the same methodology and statistical approach and are based on the same type of substrate.

Svalbard and the Ross Sea are both situated in polar environments with seasonally ceasing light levels, sea-ice formation and ice-scouring, overall low temperatures, and strong fluctuations of environmental variables in the upper water column (Zacher et al. 2009). The environmental conditions in the Ross Sea are more extreme than in Svalbard, which is still in the far reach of the warm Gulf Stream. In consequence, the Mosselbukta, Svalbard, is roughly 11 months mostly ice free (see Fig. 2 in Meyer et al. 2020), whilst the Ross Sea is only roughly two months ice free (Fig. 2). Antarctica is more isolated and surrounded by the Southern Ocean and the Antarctic Circumpolar Current, whereas the Arctic is surrounded by continental land masses (e.g. Dayton et al. 1982; Zacher et al. 2009). The areas have experienced different palaeogeographic, palaeoceanographic, and palaeoclimatic evolutions that may have had an impact on the present (ichno)diversity (e.g. Clarke et al. 1992; Crame 1992; Brandt 2005; Zacher et al. 2009).

Nevertheless, in the Ross Sea, we found eighteen different ichnotaxa and in Svalbard twenty (Table 3 in Meyer et al. 2020), thus portraying a very similar ichnodiversity. The abundance of traces at both polar study sites was similar, with a few ichnotaxa being dominant at certain stations (see Table 3 and Table 3 in Meyer et al. 2020).

Six traces by phototrophic borers were observed in the Svalbard archipelago and two in the Ross Sea, which are Fascichnus frutex (by cyanobacteria) and Ichnoreticulina elegans (by chlorophytes). F. frutex was only recognised in the Ross Sea, but not in Svalbard waters, where we have recorded two other Fascichnus forms, which were, in turn, not seen in the Ross Sea. Conchocelichnus seilacheri (by rhodophytes) was occasionally dominant in Svalbard (Table 3 in Meyer et al. 2020) but did not occur in the Ross Sea. Those contrasts are likely due to the varying number of samples from the euphotic to dysphotic zone: 65 samples from Svalbard were from the euphotic and 16 from the dysphotic zone (Table 1 in Meyer et al. 2020), whereas only four samples from the Ross Sea were from the deep euphotic to dysphotic zone (Table 1). As expected, microbioerosion traces by phototrophs are rare in the Arctic and Antarctic. Cyanobacteria and chlorophytes are almost completely absent in the Ross Sea (Smith et al. 2012), as well as their traces. According to our findings, rhodophyte traces are also rare in the Ross Sea and thus likely also their producers.

The number of fungal bioerosion traces is the same at both locations, though the distribution differs. Two Flagrichnus cf. species were described from Svalbard (F. cf. baiulus and $F$. cf. profundus), and an additional Flagrichnus cf. species was recorded in the Ross Sea ( $F$. cf. profundus and Flagrichnus-form I). So far, we have no explanation why only a single colony of Saccomorpha clava was found off Svalbard, whilst the ichnotaxon was dominant in the Ross Sea, although the environmental conditions in Svalbard would be more favourable and the ichnotaxon is very common in the adjacent cold-temperate waters of the Norwegian shelf. Our observation appears to rule out temperature and sea-ice coverage as a limiting factor for its producer, the fungus Dodgella prisca Zebrowski, 1936.

The more extreme environment in the Antarctic additionally influences bioeroding foraminifera and bacteria, as Nododendrina europaea (produced by endolithic foraminifera), a very common trace in Svalbard waters, was not observed and the inferred bacterial trace Scolecia serrata, another microboring of high abundance in Svalbard, was found exclusively in the additional sample material. Both ichnotaxa were occasionally dominant and occurred almost in the entire water column off Svalbard. The 'dwarf entobian' Entobia mikra has so far primarily been recorded in cool to cold-water (palaeo)environments (Wisshak 2006, 2008), but their unknown producer seems to be limited by the harsh conditions in the studied polar environments, especially in the more extreme Ross Sea.

Four yet undiagnosed microborings (Flagrichnus-form I, Finger-form, Nidus-form, Proturbero-form) were investigated in the Ross Sea. All of them are most likely the work of marine fungi, as these traces occur primarily in aphotic water depths, and are so far only found in the Antarctic. It is possible that the specific trace makers are endemic species in Antarctica, as this biogeographic region is characterised by a high degree of endemism (as reviewed by Brandt 2005; Zacher et al. 2009).

Only a single macrobioerosion trace, Rogerella isp., an ichnogenus for very common traces produced by acrothoracid barnacles, was detected in the Ross Sea and none in Svalbard, although more samples were analysed there. As macroborers usually are not among the first to colonise substrates and commonly take a few years to establish (as described, e.g. by Farrow and Fyfe 1988; Kiene and Hutchings 1992; Wisshak 2006; Färber et al. 2016), this lack could again be due to the size and thus age of the investigated specimens, or it could reflect a general scarcity of macroborers in polar environments, as demonstrated by only a few reports on macrobioerosion traces (e.g. Aitken and Risk 1988; Hanken et al. 2012). 
Flagrichnus baiulus, Saccomorpha guttulata, and Orthogonum-form I have previously been suggested as indicators for cold-water environments in high latitudes and the deep ocean (Wisshak 2006; Wisshak and Porter 2006; Wisshak et al. 2018), a view that is supported by the present findings in the Ross Sea. Entobia mikra and Nododendrina europaea were also primarily reported from cold environments (Wisshak 2008), including Svalbard (Meyer et al. 2020), but were not detected in the Ross Sea. Therefore, we assume that their producers are either somewhat less well adapted to polar environmental conditions or that their biogeographic range does not extend that far south. Saccomorpha terminalis and Saccomorpha stereodiktyon are further microborings commonly associated with cold-water environments (Wisshak 2006), but were found neither in our Svalbard study, nor in the present study, suggesting that their producers are limited by polar environmental conditions.

For both study sites, the performed statistical tests indicate that depth (i.e. availability of light) is a significant driver for the development of different microbioerosion trace assemblages across the bathymetric range. While this observation was very clear in Svalbard (ANOSIM, $R=0.80$; Meyer et al. 2020), the statistical difference was less significant for the Ross Sea (ANOSIM, $R=0.50$ ), because most samples were from the aphotic zone.

\section{Conclusions}

This study provides a first comprehensive ichnotaxa list from the Ross Sea, Antarctica, where eighteen different bioerosion traces were recorded in barnacles. These traces are produced by cyanobacteria (1), chlorophytes (1), fungi (9), foraminifera (1), barnacles (1), bacteria (1), and unknown organotrophs (4), most of which were also recorded for the first time in deep waters down to bathyal $1680 \mathrm{~m}$ water depth. Together with our corresponding study from the Arctic Svalbard archipelago (Meyer et al. 2020), these data help constraining the ecophysiological limits of the producers of certain key ichnotaxa several of which are considered indicative for cool to cold-water environments (foremost Flagrichnus baiulus and Saccomorpha guttulata). Statistical tests indicated only minor differences between groups from different water depths, as the samples came mainly from the aphotic zone. The ichnospecies richness was only slightly lower than what has been recorded in the Svalbard study (18 vs. 20 ichnotaxa), suggesting a comparable overall ichnodiversity of microbioerosion traces in the two polar regions. As a lack of shallow-water samples of the Antarctic region made it difficult to draw conclusions about intertidal ichnodiversity, also other substrates should be considered in future studies to obtain a better picture of euphotic shallow-water and intertidal bioerosion in Antarctica. More studies of bioerosion patterns from the Arctic and Southern Oceans are needed to develop a data base that allows more general conclusions on the biogeographic distribution of bioerosion traces and their producers for the overall aim of a better understanding of the bioerosion process in polar environments.

Acknowledgements Sample material was kindly provided by the NIWA Invertebrate Collection and we acknowledge the identifying taxonomist of the material as well as the following research program(s) that funded collections: Samples collected on voyage TAN0402: A biodiversity survey of the western Ross Sea and Balleny Islands in 2004 undertaken by the National Institute of Water \& Atmospheric Research and financed by the former New Zealand Ministry of Fisheries. Samples collected on voyage TAN0802: This research was funded by the New Zealand Government under the New Zealand International Polar Year Census of Antarctic Marine Life Project (Phase 1: So001IPY; Phase 2; IPY2007-01). We gratefully acknowledge project governance provided by the Ministry of Fisheries Science Team and the Ocean Survey 20/20 CAML Advisory Group (Land Information New Zealand, Ministry of Fisheries, Antarctica New Zealand, Ministry of Foreign Affairs and Trade, and National Institute of Water and Atmospheric Research). Samples collected on voyages beginning with TRIP: Ben Sharp, New Zealand Scientific Committee representative to the Commission for the Conservation of Antarctic Marine Living Resources (CCAMLR) Convention, for approving the provision of the sample data, MPI and CCAMLR Observers for collecting the samples at sea. Steve Parker (NIWA) for coordinating the collection of CCAMLR VME program samples. We are deeply thankful for NIWA Invertebrate Collection manager Sadie Mills, as well as her colleagues Diana Macpherson, Di Tracey, and Sophie Mormede, who provided access to samples and sample data. Additionally, we are very thankful for additional sample material from Marco Taviani (ISMAR-CNR, Bologna, Italy). We acknowledge Christine Schönberg (National Sun Yat-sen University, Department of Marine Science, Taiwan) for her advice on statistics and Barbara Domenighini (Master student at the University of Bremen) for her help during material preparation. We also thank the reviewers Tracy Frank, Alec E. Aitken and an anonymous reviewer for their constructive comments and suggestions on the manuscript that helped us to improve it.

Author contributions Conception and funding of the project was established by MW and all authors contributed to the outline of the present case study. Material preparation, data collection and analysis were performed by NM. The manuscript was written by NM with contributions by all co-authors. All authors read and approved the final manuscript.

Funding Open Access funding enabled and organized by Projekt DEAL. This study was funded by the German Research Foundation (DFG) under grant WI 3754/3-1.

Code availability Please see software application and list of utilised R packages in the "Materials and methods" section.

\section{Compliance with ethical standards}

Conflicts of interest The authors declare that they have no conflict of interest.

Open Access This article is licensed under a Creative Commons Attribution 4.0 International License, which permits use, sharing, adaptation, distribution and reproduction in any medium or format, as long 
as you give appropriate credit to the original author(s) and the source, provide a link to the Creative Commons licence, and indicate if changes were made. The images or other third party material in this article are included in the article's Creative Commons licence, unless indicated otherwise in a credit line to the material. If material is not included in the article's Creative Commons licence and your intended use is not permitted by statutory regulation or exceeds the permitted use, you will need to obtain permission directly from the copyright holder. To view a copy of this licence, visit http://creativecommons.org/licenses/by/4.0/.

\section{References}

Aguirre ML, Richiano S, Voelker AHL, Dettman DL, Schöne BR, Panarello HO, Donato M, Peral LG, Castro LE, Medina R (2019) Late Quaternary nearshore molluscan patterns from Patagonia Windows to southern southwestern Atlantic-Southern Ocean palaeoclimate and biodiversity changes? Global Planet Change 181. https://doi.org/10.1016/j.gloplacha.2019.102990

Aitken AE, Risk MJ (1988) Biotic interactions revealed by macroborings in Arctic bivalve molluscs. Lethaia 21:339-350. https://doi. org/10.1111/j.1502-3931.1988.tb01762.x

Akpan EB, Farrow GE (1985) Shell bioerosion in high-latitude lowenergy environments: Firths of Clyde and Lorne, Scotland. Mar Geol 67:139-150. https://doi.org/10.1016/0025-3227(85)90152-5

Alexander SP, DeLaca TE (1987) Feeding adaptations of the foraminiferan Cibicides refulgens living epizoically and parasitically on the Antarctic scallop Adamussium colbecki. Biol Bull 173:136-159. https://doi.org/10.2307/1541868

Arndt JE, Schenke HW, Jakobsson M, Nitsche F-O, Buys G, Goleby B, Rebesco M, Bohoyo F, Hong JK, Black J, Greku RK, Udintsev GB, Barrios F, Reynoso-Peralta W, Taisei M, Wigley R (2013) The International bathymetric chart of the Southern Ocean (IBCSO) - digital bathymetric model. Pangaea. https://doi.org/ 10.1594/PANGAEA.805734

Asper VL, Smith WO Jr (1999) Particle fluxes during austral spring and summer in the southern Ross Sea, Antarctica. J Geophys Res 104:5345-5359. https://doi.org/10.1029/1998JC900067

Azzaro M, La Ferla R, Azzaro F (2006) Microbial respiration in the aphotic zone of the Ross Sea (Antarctica). Mar Chem 99:199-209. https://doi.org/10.1016/j.marchem.2005.09.011

Bornet ÉM, Flahault C (1889) Sur quelques plantes vivant dans le test calcaire des mollusques. Bull Soc Bot France 36:147-179. https:// doi.org/10.1080/00378941.1889.10835893

Beuck L, Freiwald A (2005) Bioerosion patterns in a deep-water Lophelia pertusa (Scleractinia) thicket (Propeller Mound, northern Porcupine Seabight). In: Freiwald A, Roberts JM (eds) Coldwater corals and ecosystems. Springer, Berlin, Heidelberg, pp 915-936. https://doi.org/10.1007/3-540-27673-4_47

Brandt A (2005) Evolution of Antarctic biodiversity in the context of the past: the importance of the Southern Ocean deep sea. Antarct Sci 17:509-521. https://doi.org/10.1017/S0954102005002932

Brandt A, Linse K, Schüller M (2009) Bathymetric distribution patterns of Southern Ocean macrofaunal taxa: Bivalvia, Gastropoda, Isopoda and Polychaeta. Deep-Sea Res Pt I 56:2013-2025. https:// doi.org/10.1016/j.dsr.2009.06.007

Budd DA, Perkins RD (1980) Bathymetric zonation and paleoecological significance of microborings in Puerto Rican shelf and slope sediments. J Sediment Res 50:881-903. https://doi.org/10.1306/ 212F7B17-2B24-11D7-8648000102C1865D

Burgess SN, Henderson GM, Hall BL (2010) Reconstructing Holocene conditions under the McMurdo Ice Shelf using Antarctic barnacle shells. Earth Planet Sc Lett 298:385-393. https://doi.org/10. 1016/j.eps1.2010.08.015
Casadío S, Marenssi SA, Santillana SN (2001) Endolithic bioerosion traces attributed to boring bryozoans in the Eocene of Antarctica. Ameghiniana 38:321-329

Casadío S, Parras A, Griffin M, Marenssi S (2007) Borers and encrusters as indicators of the presence of hermit crabs in Antarctic Eocene gastropods shells. Antarct Sci 19:297-309. https://doi. org/10.1017/S0954102007000533

Cerrano C, Bavestrello G, Calcinai B, Cattaneo-Vietti R, Chiantore M, Guidetti M, Sarà A (2001) Bioerosive processes in Antarctic seas. Polar Biol 24:790-792. https://doi.org/10.1007/s003000100294

Chazottes V, Le Campion-Alsumard T, Peyrot-Clausade M (1995) Bioerosion rates on coral reefs: Interactions between macroborers, microborers and grazers (Moorea, French Polynesia). Palaeogeogr Palaeocl 113:189-198. https://doi.org/10.1016/0031-0182(95) 00043-L

Clarke A, Crame JA, Strömberg J-O, Barker PF, Drewry DJ, Laws RM, Pyle JA (1992) The Southern Ocean benthic fauna and climate change: a historical perspective. Philos T Roy Soc B 338:299_ 309. https://doi.org/10.1098/rstb.1992.0150

Clarke A, Griffiths HJ, Linse K, Barnes DKA, Crame JA (2007) How well do we know the Antarctic marine fauna? A preliminary study of macroecological and biogeographical patterns in Southern Ocean gastropod and bivalve molluscs. Divers and Distrib 13:620-632. https://doi.org/10.1111/j.1472-4642.2007.00380.x

Crame JA (1992) Evolutionary history of the polar regions. Hist Biol 6:37-60. https://doi.org/10.1080/10292389209380417

Dayton PK, Newman WA, Oliver J (1982) The vertical zonation of the deep-sea Antarctic acorn barnacle, Bathylasma corolliforme (Hoek): experimental transplants from the shelf into shallow water. J Biogeogr 9:95-109. https://doi.org/10.2307/2844695

de Saint-Seine R (1951) Un Cirripèdes acrothoraciques du Crétacé: Rogerella lecointrei nov. gen., nov. sp. C R Acad Sci 233:1051-1054

Dowdeswell JA, Bamber JL (2007) Keel depths of modern Antarctic icebergs and implications for sea-floor scouring in the geological record. Mar Geol 243:120-131. https://doi.org/10.1016/j.margeo. 2007.04.008

El-Sayed SZ, Biggs DC, Holm-Hansen O (1983) Phytoplankton standing crop, primary productivity, and near-surface nitrogenous nutrient fields in the Ross Sea, Antarctica. Deep Sea Res Pt A 30:871-886. https://doi.org/10.1016/0198-0149(83)90005-5

Fabiano M, Povero P, Danovaro R (1993) Distribution and composition of particulate organic matter in the Ross Sea (Antarctica). Polar Biol 13:525-533. https://doi.org/10.1007/BF00236394

Färber C, Titschack J, Schönberg CHL, Ehrig K, Boos K, Baum D, Illerhaus B, Asgaard U, Bromley RG, Freiwald A (2016) Longterm macrobioerosion in the Mediterranean Sea assessed by micro-computed tomography. Biogeosciences 13:3461-3474. https://doi.org/10.5194/bg-13-3461-2016

Färber C, Wisshak M, Pyko I, Bellou N, Freiwald A (2015) Effects of water depth, seasonal exposure, and substrate orientation on microbial bioerosion in the Ionian Sea (Eastern Mediterranean). PLoS ONE 10:e0126495. https://doi.org/10.1371/journal.pone. 0126495

Farrow GE, Fyfe JA (1988) Bioerosion and carbonate mud production on high-latitude shelves. Sediment Geol 60:281-297. https://doi. org/10.1016/0037-0738(88)90125-X

Fetterer F, Knowles K, Meier WN, Savoie M, Windnagel AK (2017, updated daily) Sea Ice Index, Version 3. Boulder, Colorado, USA. https://nsidc.org/data/G02135/versions/3. Accessed 08 June 2020. https://doi.org/10.7265/N5K072F8

Feussner K-D, Skelton PA, South G, Alderslade P, Aalbersberg W (2004) Ostreobium quekettii (Ostreobiaceae: Chlorophyceae) invading the barnacle Acasta sp. (Pendunculata: Acastinae), endozoic in the octocoral Rumphella suffruticosa (Alcyonacea: 
Gorgoniidae) from Fiji, South Pacific. New Zeal J Mar Fresh 38:87-90. https://doi.org/10.1080/00288330.2004.9517220

Frank TD, James NP, Bone Y, Malcolm I, Bobak LE (2014) Late Quaternary carbonate deposition at the bottom of the world. Sediment Geol 305:1-16. https://doi.org/10.1016/j.sedgeo.2014.02.008

Frank TD, James NP, Shultis AI (2020) Lack of synsedimentary chemical alteration in polar carbonates (Ross Sea, Antarctica): Resolution of a conundrum. J Sediment Res 90:449-467. https://doi.org/ $10.2110 /$ jsr.2020.26

Glaub I (1994) Mikrobohrspuren in ausgewählten Ablagerungsräumen des europäischen Jura und der Unterkreide (Klassifikation und Palökologie). Cour Forsch Senckenberg 174. Senckenbergische Naturforschende Gesellschaft, Frankfurt am Main

Glaub I, Gektidis M, Vogel K (2002) Microborings from different North Atlantic shelf areas - variability of the euphotic zone extension and implications for paleodepth reconstructions. Cour Forsch Senckenberg 237:25-37

Golubic S, Brent G, Le Campion T (1970) Scanning electron microscopy of endolithic algae and fungi using a multipurpose castingembedding technique. Lethaia 3:203-209. https://doi.org/10. 1111/j.1502-3931.1970.tb01858.x

Golubic S, Perkins RD, Lukas KJ (1975) Boring microorganisms and microborings in carbonate substrates. In: Frey RW (ed) The Study of Trace Fossils: A Synthesis of Principles, Problems, and Procedures in Ichnology. Springer, Berlin, Heidelberg. https://doi.org/ 10.1007/978-3-642-65923-2_12

Golubic S, Radtke G, Le Campion-Alsumard T (2005) Endolithic fungi in marine ecosystems. Trends Microbiol 13:229-235. https://doi. org/10.1016/j.tim.2005.03.007

Gordon AL, Huber BA, Busecke J (2015) Bottom water export from the western Ross Sea, 2007 through 2010. Geophys Res Lett 42:5387-5394. https://doi.org/10.1002/2015GL064457

Greenacre M, Primicerio R (2013) Multivariate analysis of ecological data. Fundacion BBVA.

Halpern BS, Walbridge S, Selkoe KA, Kappel CV, Micheli F, D’Agrosa C, Bruno JF, Casey KS, Ebert C, Fox HE, Fujita R, Heinemann D, Lenihan HS, Madin EMP, Perry MT, Selig ER, Spalding M, Steneck R, Watson R (2008) A global map of human impact on marine ecosystems. Science 319:948-952. https://doi.org/10. $1126 /$ science. 1149345

Hammer Ø, Harper DA (2008) Paleontological data analysis. Blackwell Publishing, Oxford. https://doi.org/10.1002/9780470750711

Hancock LG, Walker SE, Pérez-Huerta A, Bowser SS (2015) Population dynamics and parasite load of a foraminifer on its Antarctic scallop host with their carbonate biomass contributions. PLoS ONE 10:e0132534. https://doi.org/10.1371/journal.pone.0132534

Hanken N, Uchman A, Jakobsen SL (2012) Late Pleistocene-early Holocene polychaete borings in NE Spitsbergen and their palaeoecological and climatic implications: An example from the Basissletta area. Boreas 41:42-55. https://doi.org/10.1111/j.15023885.2011.00223.x

Hoek PPC (1883) Report on the Cirripedia collected by HMS Challenger during the years 1873-1876. In: Thomson CW, Murray J (eds) Report of the scientific results of the voyage of H.M.S. Challenger during the years 1873-76 under the command of Captain George S. Nares and Captain Frank Tourle Thomson, 8. Zoology, London, Edinburgh, Dublin, pp 1-169

Hook JE, Golubic S (1993) Microbial shell destruction in deep-sea mussels, Florida Escarpment. Mar Ecol 14:81-89. https://doi.org/ 10.1111/j.1439-0485.1993.tb00366.x

Hook JE, Golubic S, Milliman JD (1984) Micritic cement in microborings is not necessarily a shallow-water indicator. J Sediment Res 54:425-431. https://doi.org/10.1306/212F8431-2B24-11D7$8648000102 \mathrm{C} 1865 \mathrm{D}$

Hutchings PA (1986) Biological destruction of coral reefs. Coral Reefs 4:239-252. https://doi.org/10.1007/BF00298083
Ituarte C, Cremonte F, Zelaya DG (2005) Parasite-mediated shell alterations in Recent and Holocene sub-Antarctic bivalves: the parasite as modeler of host reaction. Invertebr Biol 124:220-229. https://doi.org/10.1111/j.1744-7410.2005.00021.x

Kiene WE, Hutchings PA (1992) Long-term bioerosion of experimental coral substrates from Lizard Island, Great Barrier Reef. Proc 7th Int Coral Reef Symp 1:397-403

Kiene WE, Hutchings PA (1994) Bioerosion experiments at Lizard Island, Great Barrier Reef. Coral Reefs 13:91-98. https://doi.org/ 10.1007/BF00300767

Korkmaz S, Goksuluk D, Zararsiz G (2014) An R package for assessing multivariate normality. R J 6:151-162

Lukas KJ, Golubic S (1983) New endolithic cyanophytes from the North Atlantic Ocean. II. Hyella gigas Lukas \& Golubic sp. nov. from the Florida Continental Margin. J Phycol 19:129-136. https://doi.org/10.1111/j.0022-3646.1983.00129.x

Malumián N, López Cabrera MI, Náñez C, Olivero EB (2006) Bioerosion patterns in Cretaceous-Cenozoic benthic foraminiferal tests from Patagonia and Tierra del Fuego Island, Argentina. SEPM Spec Publ 88:299-306. https://doi.org/10.2110/pec.07.88.0301

Meyer N, Wisshak M, Freiwald A (2020) Ichnodiversity and bathymetric range of microbioerosion traces in polar barnacles of Svalbard. Polar Res 39. https://doi.org/10.33265/polar.v39.3766

Mouginot J, Scheuchl B, Rignot E (2017) MEaSUREs Antarctic Boundaries for IPY 2007-2009 from Satellite Radar, Version 2. IceShelf_Antarctica_v02. Boulder, Colorado USA. https://doi.org/ 10.5067/AXE4121732AD

Neumann AC (1966) Observations on coastal erosion in Bermuda and measurements of the boring rate of the sponge, Cliona lampa. Limnol Oceanogr 11:92-108. https://doi.org/10.4319/lo.1966. 11.1.0092

Newman WA, Ross A (1971) Antarctic Cirripedia 14. American Geophysical Union, Antarctic Research Series. https://doi.org/10. 1029/AR014

Oksanen J, Blanchet FG, Friendly M, Kindt R, Legendre P, McGlinn D, Minchin PR, O’Hara RB, Simpson GL, Solymos P, Henry M, Stevens H, Szoecs E, Wagner H (2018) vegan: Community Ecology Package. R package version 2:5-3

Parkinson CL (2004) Southern Ocean sea ice and its wider linkages: insights revealed from models and observations. Antarct Sci 16:387-400. https://doi.org/10.1017/S0954102004002214

Radtke G (1991) Die mikroendolithischen Spurenfossilien im Alt-Tertiär West-Europas und ihre palökologische Bedeutung, vol 138. Cour Forsch Senckenberg, Senckenbergische Naturforschende Gesellschaft, Frankfurt am Main

R Core Team (2019) R: A Language and Environment for Statistical Computing. R Foundation for Statistical Computing, Vienna, Austria

Richiano S, Aguirre M, Castellanos I, Davies K, Farinati E (2017) Do coastal fronts influence bioerosion patterns along Patagonia? Late Quaternary ichnological tools from Golfo San Jorge. J Mar Syst 176:38-53. https://doi.org/10.1016/j.jmarsys.2017.07.010

Smith WO Jr, Ainley DG, Cattaneo-Vietti R, Hofmann EE (2012) The Ross Sea continental shelf: Regional biogeochemical cycles, trophic interactions, and potential future changes. In: Rogers AD, Johnston NM, Murphy EJ, Clarke A (eds) Antarctic Ecosystems. https://doi.org/10.1002/9781444347241.ch7

Schmidt H (1992) Mikrobohrspuren ausgewählter Faziesbereiche der tethyalen und germanischen Trias (Beschreibung, Vergleich und bathymetrische Interpretation). Frankfurter geowissenschaftliche Arbeiten 12, Frankfurt am Main

Schmidt H, Freiwald A (1993) Rezente gesteinsbohrende Kleinorganismen des norwegischen Schelfs. Nat Mus 123:149-155

Smith WO Jr, Ainley DG, Arrigo KR, Dinniman MS (2014) The oceanography and ecology of the Ross Sea. Annu Rev Mar Sci 6:469487. https://doi.org/10.1146/annurev-marine-010213-135114 
Smith WO Jr, Ainley DG, Cattaneo-Vietti R (2007) Trophic interactions within the Ross Sea continental shelf ecosystem. Philos Trans R Soc Lond B Biol Sci 362:95-111. https://doi.org/10. 1098/rstb.2006.1956

Smith WO Jr, Marra J, Hiscock MR, Barber RT (2000) The seasonal cycle of phytoplankton biomass and primary productivity in the Ross Sea, Antarctica. Deep Sea Res Part II: Top Stud Oceanogr 47:3119-3140. https://doi.org/10.1016/S0967-0645(00)00061-8

Smith WO Jr, Tozzi S, Long MC, Sedwick PN, Peloquin JA, Dunbar RB, Hutchins DA, Kolber Z, DiTullio GR (2013) Spatial and temporal variations in variable fluoresence in the Ross Sea (Antarctica): Oceanographic correlates and bloom dynamics. Deep Sea Res Part I: Oceanogr Res Pap 79:141-155. https://doi.org/ 10.1016/j.dsr.2013.05.002

Taviani M, Reid DE, Anderson JB (1993) Skeletal and isotopic composition and paleoclimatic significance of Late Pleistocene carbonates, Ross Sea, Antarctica. J Sediment Res 63:84-90. https://doi. org/10.1306/D4267A96-2B26-11D7-8648000102C1865D

Thorsen S (1995-2020) McMurdo, Antarctica - Sunrise, Sunset, and Daylength, 2004. https://www.timeanddate.com/sun/antarctica/ mcmurdo?month $=9$ \&year $=2004$. Accessed 08 January 2020

Tribollet A (2008) The boring microflora in modern coral reef ecosystems: a review of its roles. In: Wisshak M, Tapanila L (eds) Current developments in Bioerosion. Springer, Berlin, Heidelberg, pp 67-94. https://doi.org/10.1007/978-3-540-77598-0_4

Tribollet A, Golubic S (2005) Cross-shelf differences in the pattern and pace of bioerosion of experimental carbonate substrates exposed for 3 years on the northern Great Barrier Reef, Australia. Coral Reefs 24:422-434. https://doi.org/10.1007/s00338-005-0003-7

Vogel K, Gektidis M, Golubic S, Kiene WE, Radtke G (2000) Experimental studies on microbial bioerosion at Lee Stocking Island, Bahamas and One Tree Island, Great Barrier Reef, Australia: implications for paleoecological reconstructions. Lethaia 33:190 204. https://doi.org/10.1080/00241160025100053

Warme JE (1975) Borings as trace fossils, and the processes of marine bioerosion. In: Frey RW (ed) The study of trace fossils. Springer, Berlin, Heidelberg, pp 181-227. https://doi.org/10.1007/978-3642-65923-2_11

Whitaker D, Christman M (2014) clustsig: Significant cluster analysis. $\mathrm{R}$ package version $1: 1$

Wisshak M (2006) High-latitude bioerosion: The Kosterfjord experiment. Lecture Notes in Earth Science 109. Springer, Berlin, Heidelberg, p. 202. https://doi.org/10.1007/978-3-540-36849-6

Wisshak M (2008) Two new dwarf Entobia ichnospecies in a diverse aphotic ichnocoenosis (Pleistocene / Rhodes, Greece). In: Wisshak M, Tapanila L (eds) Current Developments in Bioerosion. Springer, Berlin, Heidelberg, pp 213-234. https://doi.org/10.1007/ 978-3-540-77598-0_11

Wisshak M (2012) Microbioerosion. In: Knaust D, Bromley RG (eds) Trace Fossils as Indicators of Sedimentary Environments, 64.
Elsevier, pp 213-243. https://doi.org/10.1016/B978-0-444-538130.00008-3

Wisshak M (2017) Taming an ichnotaxonomical Pandora's box: Revision of dendritic and rosetted microborings (ichnofamily: Dendrinidae). Eur J Taxon 390:1-99. https://doi.org/10.5852/ejt.2017. 390

Wisshak M, López Correa M, Zibrowius H, Jakobsen J, Freiwald A (2009) Skeletal reorganisation affects geochemical signals, exemplified in the stylasterid hydrocoral Errina dabneyi (Azores Archipelago). Mar Ecol Prog Ser 397:197-208. https://doi.org/ 10.3354/meps08165

Wisshak M, Gektidis M, Freiwald A, Lundälv T (2005) Bioerosion along a bathymetric gradient in a cold-temperate setting (Kosterfjord, SW Sweden): an experimental study. Facies 51:93-117. https://doi.org/10.1007/s10347-005-0009-1

Wisshak M, Knaust D, Bertling M (2019) Bioerosion ichnotaxa: review and annotated list. Facies 65:24 pp. https://doi.org/10.1007/ s10347-019-0561-8

Wisshak M, Meyer N, Radtke G, Golubic S (2018) Saccomorpha guttulata: a new marine fungal microbioerosion trace fossil from cool- to cold-water settings. PalZ 92:525-533. https://doi.org/10. 1007/s12542-018-0407-7

Wisshak M, Porter D (2006) The new ichnogenus Flagrichnus - A paleoenvironmental indicator for cold-water settings? Ichnos 13:135-145. https://doi.org/10.1080/10420940600851255

Wisshak M, Tribollet A, Golubic S, Jakobsen JC, Freiwald A (2011) Temperate bioerosion: Ichnodiversity and biodiversity from intertidal to bathyal depths (Azores). Geobiology 9:492-520. https:// doi.org/10.1111/j.1472-4669.2011.00299.x

Young HR, Nelson CS (1988) Endolithic biodegradation of cool-water skeletal carbonates on Scott shelf, northwestern Vancouver Island, Canada. Sediment Geol 60:251-267. https://doi.org/10.1016/ 0037-0738(88)90123-6

Zacher K, Rautenberger R, Hanelt D, Wulff A, Wiencke C (2009) The abiotic environment of polar marine benthic algae. Bot Mar 52: 483-490

Zebrowski G (1936) New genera of cladochytriaceae. Ann Missouri Bot Gard 23:553-564. https://doi.org/10.2307/2394150

Zeff ML, Perkins RD (1979) Microbial alteration of Bahamian deepsea carbonates. Sedimentology 26:175-201. https://doi.org/10. 1111/j.1365-3091.1979.tb00350.x

Publisher's Note Springer Nature remains neutral with regard to jurisdictional claims in published maps and institutional affiliations. 